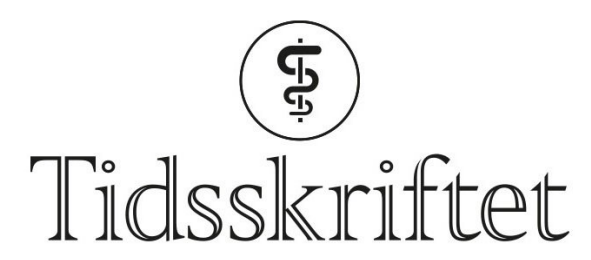

DEN NORSKE LEGEFORENING

\title{
Kan man «ta opp» en journal?
}

SPRÅKSPALTEN

\section{JON HÅVARD LOGE}

E-post: j.h.loge@medisin.uio.no

Jon Håvard Loge (f. 1953) er dr.med., leder for Regional kompetansetjeneste for lindrende behandling, Helse Sør-Øst, Avdeling for kreftbehandling, Oslo universitetssykehus, og professor ved Avdeling for medisinsk atferdsvitenskap, Universitetet i Oslo.

Alle leger snakker om å «ta opp en journal» og å «gjøre et journalopptak». Jeg stusser over uttrykksmåten.

Journalopptaket innebærer vanligvis tre elementer: samtale, undersøkelse og etterfølgende nedtegnelser (1). Jeg synes betegnelsen «journalopptak» er lite heldig. Et «opptak» gir inntrykk av at legen tar opp noe, mens det som i virkeligheten skjer i møtet mellom lege og pasient, er preget av samspill, samarbeid og dialog. Jeg tror heller ikke at uttrykket er særlig forståelig for pasientene.

Jeg strever likevel med åfinne et godt alternativ. En variant kan kanskje være «Nå skalvigjennomgå sykehistorien din og så skal jeg undersøke deg». Hva mener språkspalten? Les svaret fra Erlend Hem.

\section{LITTERATUR:}

1. Journalopptak. Journalwiki. Universitetet i Oslo.

http://meddev.uio.no/journalwiki/index.php/Journalopptak (28.4.2017).

Publisert: 18. september 2017. Tidsskr Nor Legeforen. DOI: 10.4045/tidsskr.17.0626

(C) Tidsskrift for Den norske legeforening 2020. Lastet ned fra tidsskriftet.no 